І. В. САНІнА, завідувач відділу гідрогеологічних, інженерно-геологічних та еколого-геологічних досліджень (Український геологорозвідувальний інститут УГК), ekogeol@ukr.net, https://orcid.org/0000-00026592-9625

Н. Г. ЛютА, канд. геол.-мінерал. наук, асистент кафедри гідрогеології та інженерної геології ННІ “Інститут геології” КНУ імені Тараса Шевченка, nlyuta@ukr.net, https://orcid.org/0000-0003-4070-0944

I. SANINA, Head of the Department of Hydrogeological, Engineeringgeological and Environmental Geological Research (Ukrainian Geological Research Institute of the UGC), ekogeol@ukr.net, https://orcid.org/00000002-6592-9625,

N. LYUTA, PhD (Geol. \& Mineral.), Assistant of Department of Hydrogeology and Engineering Geology, Institute of Geology Taras Shevchenko National University of Kyiv, nlyuta@ukr.net, https://orcid.org/0000-0003-4070-0944

\title{
ІДЕНТИФІКАЦІЯ ТРАНСКОРДОННИХ МАСИВІВ ПІДЗЕМНИХ ВОД (УКРАїНА - БІЛОРУСЬ, БАСЕЙН ДНІПРА)
}

\section{IDENTIFICATION OF TRANSBOUNDARY GROUNDWATER BODIES (UKRAINE - BELARUS, DNIPRO RIVER BASIN)}

\begin{abstract}
Нещодавнє дослідження “Ідентифікація та розмежування підземних водних об'єктів у басейні річки Дніпро в Україні” під егідою проєкту ЄC “Водна ініціатива Європейського Союзу плюс для країн Східного партнерства (EUWI+)" виявило вісім масивів підземних вод (МПВ) у басейні річки Дніпро в Україні. Вони транскордонні й пов'язані із шістьма відповідними МПВ у басейнах Прип'яті та Дніпра Республіки Білорусі. Деякі із цих МПВ дуже великі, тому наступне дослідження було зосереджено на виявленні частин МПВ з транскордонною взаємодією в їхніх межах. Аналіз впливу робочих водозаборів засвідчив, що транскордонну зону доцільно обмежувати 50-кілометровою смугою вздовж кордону з обох боків. 3'ясовано, що умови формування підземних водних ресурсів у транскордонній українсько-білоруській зоні в басейні Дніпра дуже сприятливі. По-перше, транскордонна територія розміщується в зоні надмірного зволоження, тож як напірні, так і безнапірні МПВ мають інфільтраційне живлення. По-друге, українська частина території, де відбувається живлення напірних МПВ, має мінімальне антропогенне навантаження. Як наслідок - кількісний і якісний стан МПВ у транскордонній зоні переважно добрий. Водночас є спільні проблеми, що потребують відновлення моніторингу підземних вод та узгодження його процедури з білоруською стороною.

Ключові слова: транскордонні підземні водні об’єкти, моніторинг, басейн річки Дніпро.
\end{abstract}

A recent study "Identification and delineation of groundwater bodies in the Dnipro River Basin in Ukraine EUWI+",identified eight groundwater bodies (GWBs) in the Dnipro River Basin of Ukraine which are transboundary linked with six corresponding GWBs in the Pripyat and Dnieper River Basins of the Republic of Belarus. Some of these GWBs are considerably large, so the next research has focused on identifying those sub-parts of the GWBs which are subject to transboundary groundwater interaction. Analysis of existing water intakes impact showed that it is advisable to limit the transboundary zone to a 50-kilometers strip along the border on both sides. Since the operation of water intakes within this zone occurs in a stationary filtration mode and the formation of groundwater reserves is provided due by dynamic resources formed as a result of infiltration of atmospheric precipitation, then to determine the radius of the influence of the operation of groundwater intakes, we used the value of river drainage module of $90 \%$ availability. At such values of the modulus of river flow formation, it occurs due to the underground flow. The forecast of transboundary impact, taking into account the maximum possible productivity at the existing water intakes with approved operational reserves, indicates that the radius of influence for the Eocene aquifer is only 3.54-9.38 km, for the Upper Cretaceous - 2.7-5.3 km, for the Albian-Cenomanian - 2.8-6.7 km, for the Precambrian $-1.7-2.3 \mathrm{~km}$. The distance from the existing water intakes to the state border of Ukraine with Belarus is 12-50, 7-50, 20-50, 30-35 kilometers, respectively.

It was established that conditions for groundwater resources formation in the transboundary Ukraine-Belarusian zone in the Dnipro basin are very favorable. First, the transboundary territory is located in a zone of excessive moisture. Recharge of the uppermost unconfined GWBs is due to the infiltration of precipitation over the entire area of their distribution. Confined aquifers also have infiltration supply, which are located in places of shallow occurrence of water-bearing rocks. Second, the Ukrainian part of the territory, where the confined aquifers are recharged, is marked by a slight anthropogenic pressure - there is a very low population density and there are no large industrial enterprises. Therefore, impacts from the Ukrainian side on the GWBs in Belarus are limited. So, both the quantitative and the qualitative status of the GWBs in the transboundary area are predominantly good. At the same time, there are common problems to be solved which require groundwater monitoring restoration and its coordination with the Belarusian side.

Keywords: transboundary groundwater bodies, monitoring, Dnipro river basin.

\section{Вступ}

Вода є найважливішим компонентом природного середовища, без якого неможливе життя на Землі. Водні ресурси, 3 огляду на тенденції до зростання навантаження на них і сталі кліматичні зміни, потребують особливої уваги.

Підземні води нині набувають значення екологічно чистого та надійно захищеного джерела забезпечення населення питною водою. Україна має великі ресурси питних підземних вод, пов'язані з відкладами архею, протерозою, палеозою, мезозою та кайнозою, які за даними регіональної оцінки становлять 61 689,2 тис. м³/д і розробляються на 1469 ділянках 702 родовищ [4]. Частина із цих водоносних систем $є$ транскордонними. Вони зазвичай об'єднують безліч споживачів 3 двох або навіть більше сторін, які експлуатують спільні водоносні горизонти. Тому вивчення транскордонних ресурсів підземних вод, забезпечення їхньої стійкості й раціонального керування та використання набуває особливого значення. Відповідно до Водної рамкової директиви й Конвенції з охорони та використання транскордонних водотоків і міжнародних озер (Гельсінкі, 1992), охорона та використання транскордонних водоносних горизонтів є важливими й невідкладними завданнями, ефективне вирішення яких може 
бути забезпечене тільки завдяки тісній міжнародній співпраці. Зокрема, це стосується прикордонної території між Україною й Білоруссю.

\section{Методи досліджень}

У межах проєкту “Водна ініціатива Європейського Союзу плюс для країн Східного партнерства (EUWI +)" на території України були визначені масиви підземних вод у басейні річки Дніпра [2]. Робота з ідентифікації транскордонних частин МПВ охоплювала збір, узагальнення та аналіз докладної інформації щодо гідрогеологічних умов транскордонної 50-кілометрової зони в межах басейну Дніпра, векторизацію картографічних матеріалів, створення та поповнення картографічної бази даних у ГІС, а також визначення радіусів впливу робочих водозаборів у прикордонній зоні. У процесі досліджень було використано державні гідрогеологічні карти України масштабу 1:200 000, матеріали Державних балансів корисних копалин України (Води питні і технічні); дані ДП “Українська геологічна компанія" про пункти спостереження Державної мережі моніторингу підземних вод, а також фондові джерела.

\section{Результати досліджень}

Вісім із загальної кількості МПВ, ідентифікованих в Україні, - транскордонні й пов'язані з відповідними МПВ у басейнах річок Прип'ять і Дніпро Республіки Білорусі. Оскільки деякі масиви підземних вод дуже великі, то надалі було визначено ті частини масивів підземних вод в Україні, які мають транскордонний характер і взаємодіють між собою. За домовленістю сторін транскордонною визнано зону, що простягається на відстань 50 км від державного кордону між Україною й Білоруссю. Дослідження тривали в тісній співпраці з експертами з питань підземних вод у Республіці Білорусі, відповідальними за розмежування підземних водних об'єктів. Подібна робота, проведена паралельно в Білорусі, дала змогу виявити шість транскордонних підземних водних масивів у Прип'ятському й Дніпровському басейнах у межах 50-кілометрової зони вздовж кордону між Україною й Білоруссю. Зіставлення масивів підземних вод, виокремлених в Україні й Білорусі, наведено в таблиці.

В Україні ідентифіковані в межах транскордонної 50-кілометрової зони МПВ розміщуються в трьох гідрогеологічних структурах першого порядку: Гідрогеологічній області Українського щита, Волино-Подільському та Дніпровсько-
Донецькому артезіанських басейнах. Ця територія належить до зони надмірного зволоження й відповідно сприятливих умов для інфільтраційного живлення підземних вод. Формування запасів підземних вод забезпечується завдяки динамічним ресурсам, що утворюються в результаті інфільтраціі атмосферних опадів. Загальний регіональний напрямок руху підземних вод спрямований від великої позитивної структури - Українського щита - на північ, захід і схід до артезіанських басейнів.

Результати просторового зіставлення транскордонних безнапірних масивів підземних вод у болотних, алювіальних, озерно-алювіальних, водно-льодовикових четвертинних відкладах, а також у палеогенових, крейдових і докембрійських відкладах наведено на рис. 1a-1e.

Як видно зі зведеної інформації, геологічні межі поширення цих підземних водних об'єктів, досліджуваних на суміжних територіях, близькі одна до одної, що дасть змогу вибрати транскордонні коридори, визначити вплив і обгрунтувати розміщення спостережної мережі моніторингу.

У транскордонній 50-кілометровій зоні безнапірні водоносні горизонти майже незахищені від забруднення, оскільки породи зони аерації характеризуються незначною потужністю (від кількох до 20-30 м) і переважно піщаним складом. Це пояснює, чому в межах населених пунктів грунтові води часто містять нітрати.

Напірні водоносні горизонти здебільшого надійно захищені від забруднення, оскільки в їхній покрівлі залягають водотривкі відклади завтовшки більш як 10 м. Зазвичай напірні підземні води захищені також і за гідродинамічними показниками. Ризики можуть виникати лише в зоні формування депресійних лійок, коли з'являються передумови для перетікання у водоносний горизонт води з інших водоносних горизонтів з підвищеною мінералізацією або підвищеним умістом забруднювальних речовин.

Для дослідження транскордонного впливу на експлуатацію підземних водоносних горизонтів у транскордонній зоні автори розрахували радіус впливу наявних водозаборів підземних вод.

Оскільки експлуатація водозаборів у межах цієї зони відбувається в стаціонарному режимі фільтрації, а формування запасів підземних вод забезпечується завдяки динамічним ресурсам, утворюваним унаслідок інфільтрації атмосферних

Таблиця. Транскордонні МПВ і групи МПВ у Білорусі та Україні

\begin{tabular}{|c|c|c|c|}
\hline \multicolumn{2}{|r|}{ Білорусь } & \multicolumn{2}{|r|}{ Україна } \\
\hline $\begin{array}{l}\text { Код і геологічний } \\
\text { індекс МПВ }\end{array}$ & МПВ & $\begin{array}{c}\text { Код і геологічний індекс } \\
\text { МПВ }\end{array}$ & МПВ \\
\hline $\begin{array}{l}\text { BYPRGW0001 } \\
\text { bIV }\end{array}$ & $\begin{array}{c}\text { водоносний голоценовий } \\
\text { болотний горизонт }\end{array}$ & $\begin{array}{l}\text { UAM5.1GW0001 } \\
\text { bP }\end{array}$ & група МПВ у болотних відкладах \\
\hline $\begin{array}{l}\text { BYPRGW0002 } \\
\text { aIV, aIIIpz, } \\
\text { laIIIpz }\end{array}$ & $\begin{array}{c}\text { водоносний голоценовий алювіальний, } \\
\text { поозерний алювіальний, поозерний } \\
\text { озерно-алювіальний горизонт(и) }\end{array}$ & $\begin{array}{l}\text { UAM5.1GW0002 } \\
\text { aP }\end{array}$ & $\begin{array}{l}\text { група МПВ в алювіальних } \\
\text { четвертинних відкладах }\end{array}$ \\
\hline $\begin{array}{l}\text { BYPRGW0005 } \\
\text { fIId }^{s}\end{array}$ & $\begin{array}{c}\text { водоносний дніпровський надморенний } \\
\text { флювіогляціальний горизонт }\end{array}$ & $\begin{array}{l}\text { UAM5.1GW0003 } \\
\text { fIIds }^{\mathrm{s}}\end{array}$ & $\begin{array}{c}\text { група МПВ у водно-льодовикових } \\
\text { четвертинних відкладах }\end{array}$ \\
\hline $\begin{array}{l}\text { BYPRGW0006 } \\
\text { f,lgIbr-IId + (P+N) }\end{array}$ & $\begin{array}{c}\text { водоносний березинсько-дніпровський } \\
\text { водно-льодовиковий і палеогеновий } \\
\text { та неогеновий комплекси }\end{array}$ & $\begin{array}{l}\text { UAM5.1GW0013 } \\
\text { i UAM5.1GW0012 } \\
\text { P i P }\end{array}$ & $\begin{array}{c}\text { група МПВ у теригенних відкладах } \\
\text { палеогену і група МПВ } \\
\text { у теригенних відкладах еоцену }\end{array}$ \\
\hline$\underset{\mathrm{K}}{\mathrm{BYPRGW} 0007}$ & $\begin{array}{c}\text { водоносний крейдовий } \\
\text { карбонатно-теригенний горизонт }\end{array}$ & $\begin{array}{l}\text { UAM5.1GW0014 } \\
\text { i UAM5.1GW0019 } \\
\text { K }_{2} \text { i K }_{1-2}\end{array}$ & $\begin{array}{c}\text { МПВ у карбонатних відкладах } \\
\text { верхньої крейди і група МПВ } \\
\text { у теригенних відкладах альб-сеноману }\end{array}$ \\
\hline $\begin{array}{l}\text { BYPRGW0009 } \\
\text { V+R } \text { R }_{2} \text { pn }\end{array}$ & $\begin{array}{l}\text { водоносний пінський і вендський } \\
\text { теригенний комплекси }\end{array}$ & $\begin{array}{l}\text { UAM5.1GW0025 } \\
\text { PE }\end{array}$ & $\begin{array}{c}\text { МПВ в ефузивно-теригенних } \\
\text { породах докембрію }\end{array}$ \\
\hline
\end{tabular}




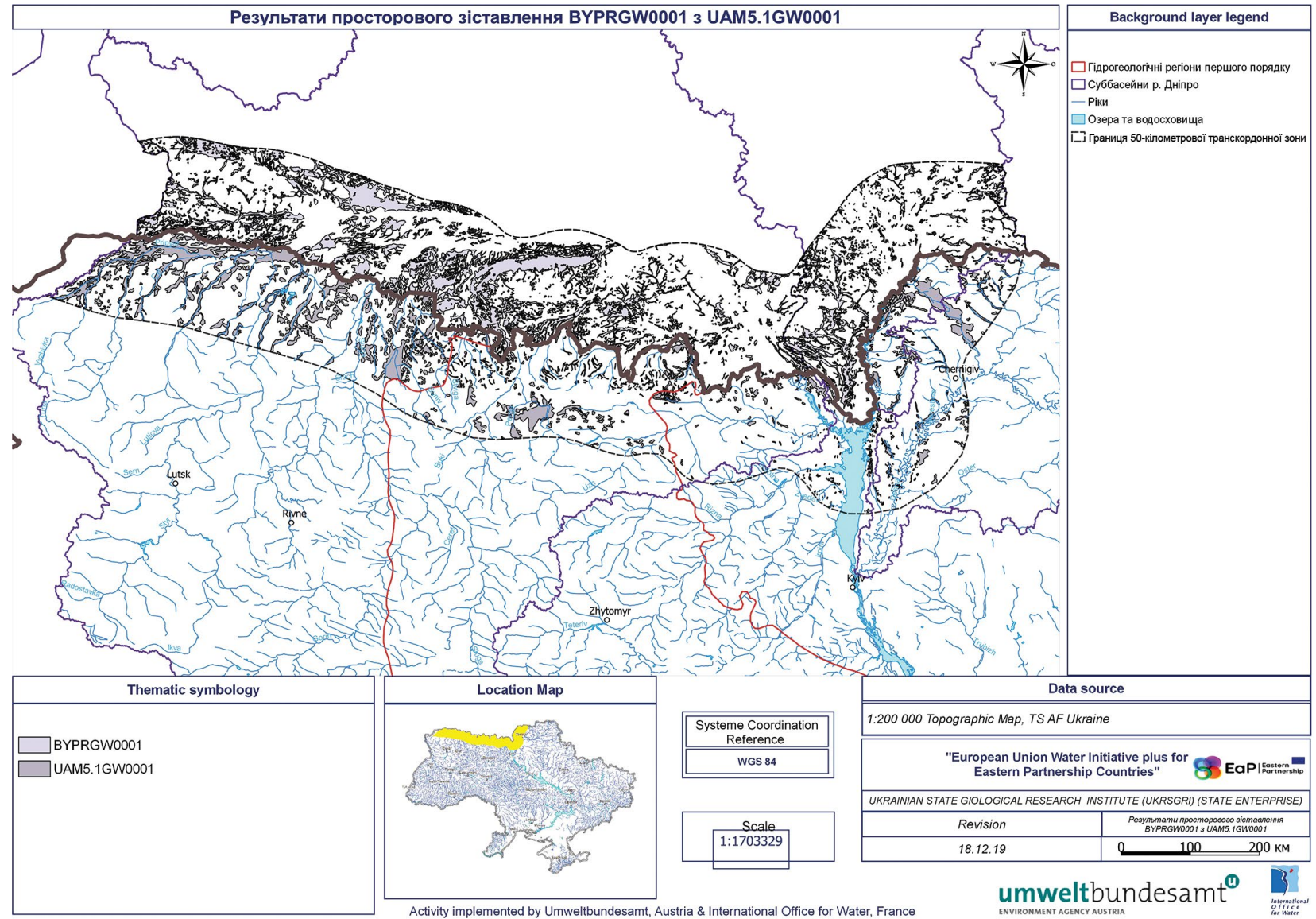

Рис. 1а. Результати просторового зіставлення транскордонних безнапірних масивів підземних вод у болотних четвертинних відкладах

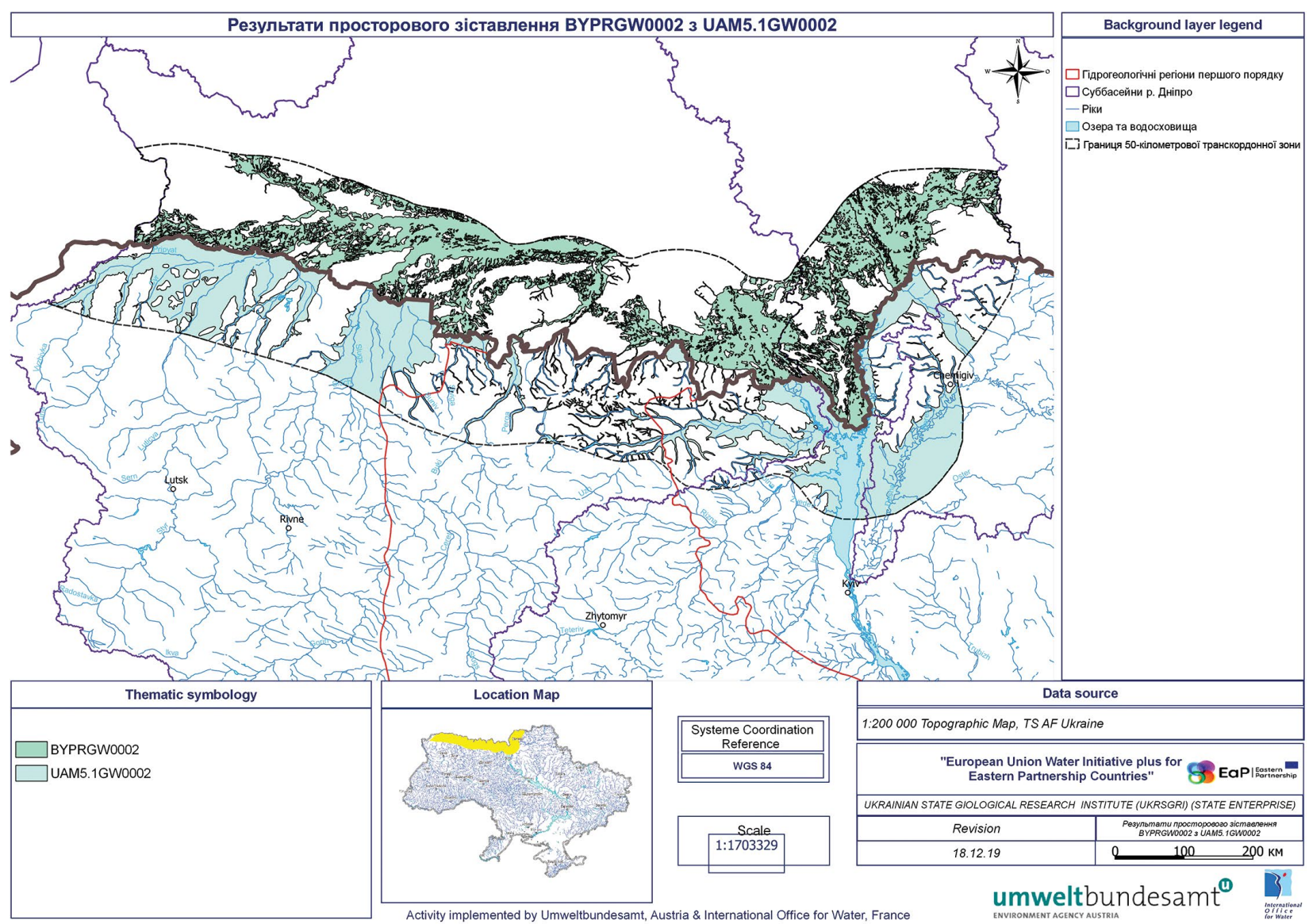

Рис. 1б. Результати просторового зіставлення транскордонних безнапірних масивів підземних вод в алювіальних, озерно-алювіальних четвертинних відкладах 


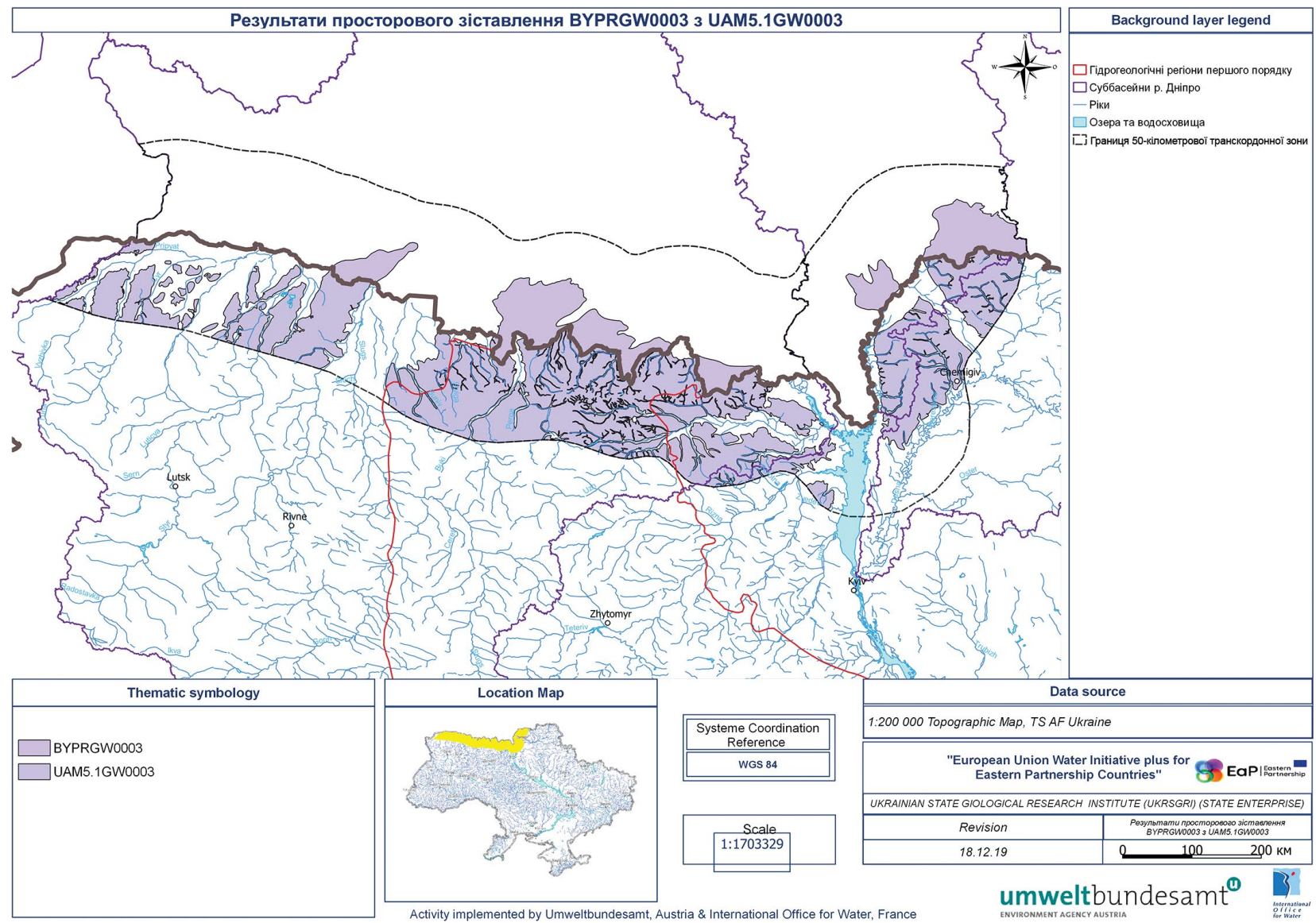

Рис. 1в. Результати просторового зіставлення транскордонних безнапірних масивів підземних вод у водно-льодовикових четвертинних відкладах

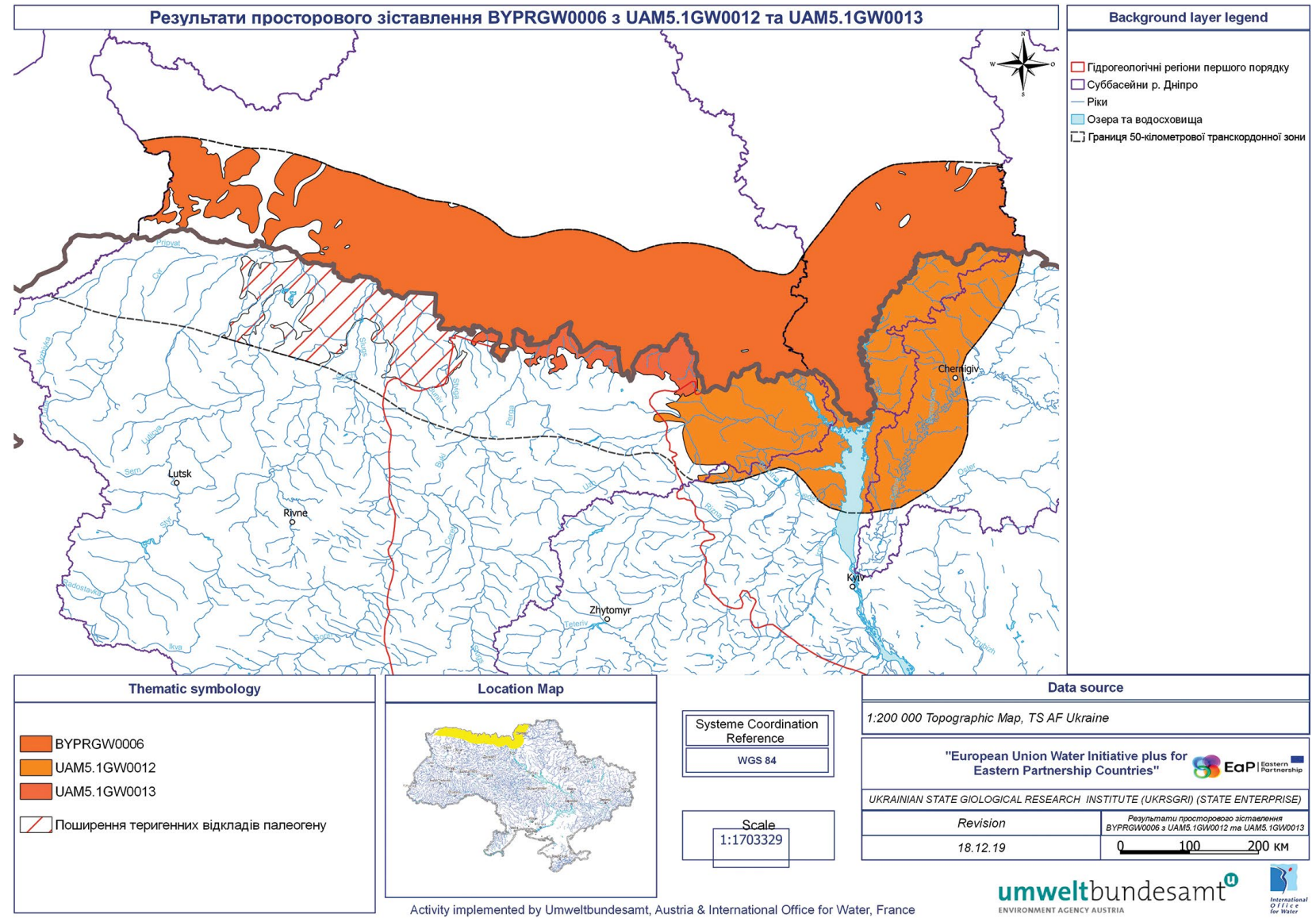

Рис. 1г. Результати просторового зіставлення транскордонних масивів підземних вод у напірних палеогенових відкладах 


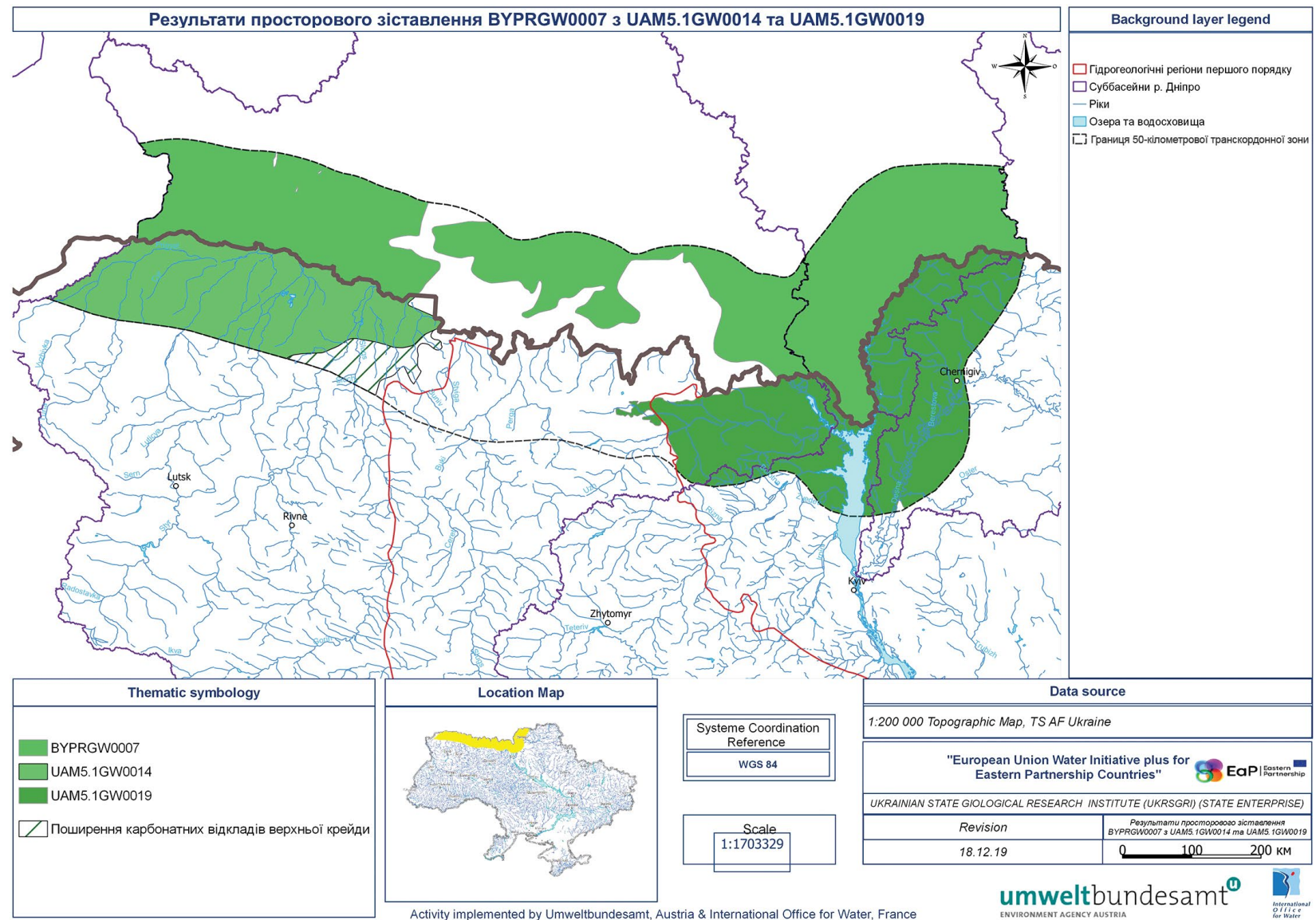

Рис. 1д. Результати просторового зіставлення транскордонних масивів підземних вод у напірних крейдових і докембрійських відкладах

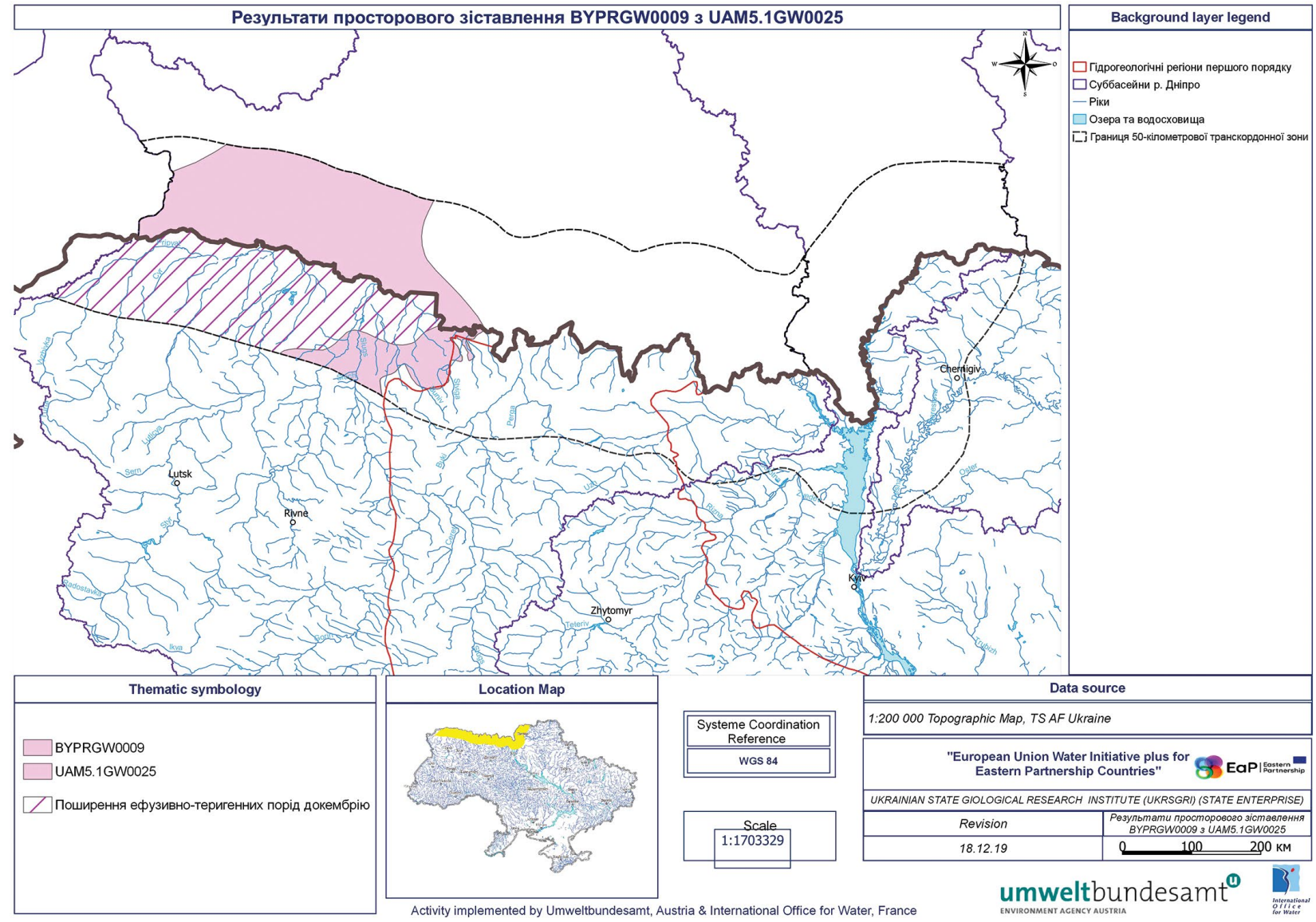

Рис. 1е. Результати просторового зіставлення транскордонних масивів підземних вод у напірних докембрійських відкладах 
опадів, то для визначення радіуса впливу експлуатації водозаборів підземних вод ми використали значення модульного живлення середньорічного річкового стоку $90 \%$ рівня забезпеченості [3]. За таких значень модуля формування річкового стоку відбувається внаслідок підземного стоку. У межах транскордонної території значення середньорічного річкового стоку 90 \% рівня забезпеченості становлять

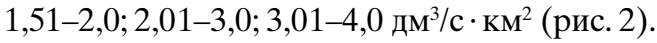

Площу можливої депресійної лійки, яка формується під час роботи водозабірних споруд, визначено за формулою

$$
S=\frac{Q}{M},
$$

де $S$ - площа депресійної лійки, утворена внаслідок роботи водозабору, км²; $Q$ - запаси (для родовищ) або видобуток (для водозаборів із незатвердженими запасами) підземних вод, дм ${ }^{3} / \mathrm{c} ; M$ - модуль річкового стоку $90 \%$ забезпеченості, $\mathrm{дM}^{3} / \mathrm{c} \cdot \mathrm{KM}^{2}$.

Показник площі депресійної лійки допоміг розрахувати радіус впливу робочого водозабору за формулою

$$
R=\sqrt{\frac{S}{\pi}},
$$

де $R$ - радіус впливу, км.

Режим груп МПВ, пов'язаних з безнапірними четвертинними горизонтами, майже природний. Підземні води живляться завдяки інфільтрації по всій площі масиву. Їх ви- користовують у сільській місцевості для господарсько-побутових потреб, де водовідбір здійснюється розосередженими водозаборами невеликої продуктивності й не має транскордонного впливу на кількісні і якісні показники підземних вод.

Визначені як транскордонні МПВ, напірні водоносні горизонти й комплекси у палеогенових, крейдових і докембрійських відкладах надійно захищені водотривами, що залягають у їхній покрівлі, і містять води доброї якості. Вони також живляться переважно завдяки інфільтрації атмосферних опадів.

Серед МПВ у палеогенових відкладах найпоширенішим $€$ водоносний горизонт у теригенних еоценових відкладах, який на території України в прикордонній $з$ Білоруссю 50-кілометровій зоні є головним та активно експлуатується для централізованого водоспоживання в ДніпровськоДонецькому артезіанському басейні.

До МПВ у крейдових відкладах належать два масиви: у карбонатних відкладах верхньої крейди та теригенних відкладах альб-сеноману. Перший з них виокремлюється в західній частині транскордонної 50-кілометрової зони в межах Волино-Подільського артезіанського басейну. Водовмісні відклади представлені тріщинуватими мергельно-крейдяними породами туронського - маастрихського ярусів. Група МПВ у теригенних відкладах альб-сеноману поширена на сході транскордонної 50-кілометрової зони в межах Дніпровсько-Донецького артезіанського басейну. Оскільки витрима-

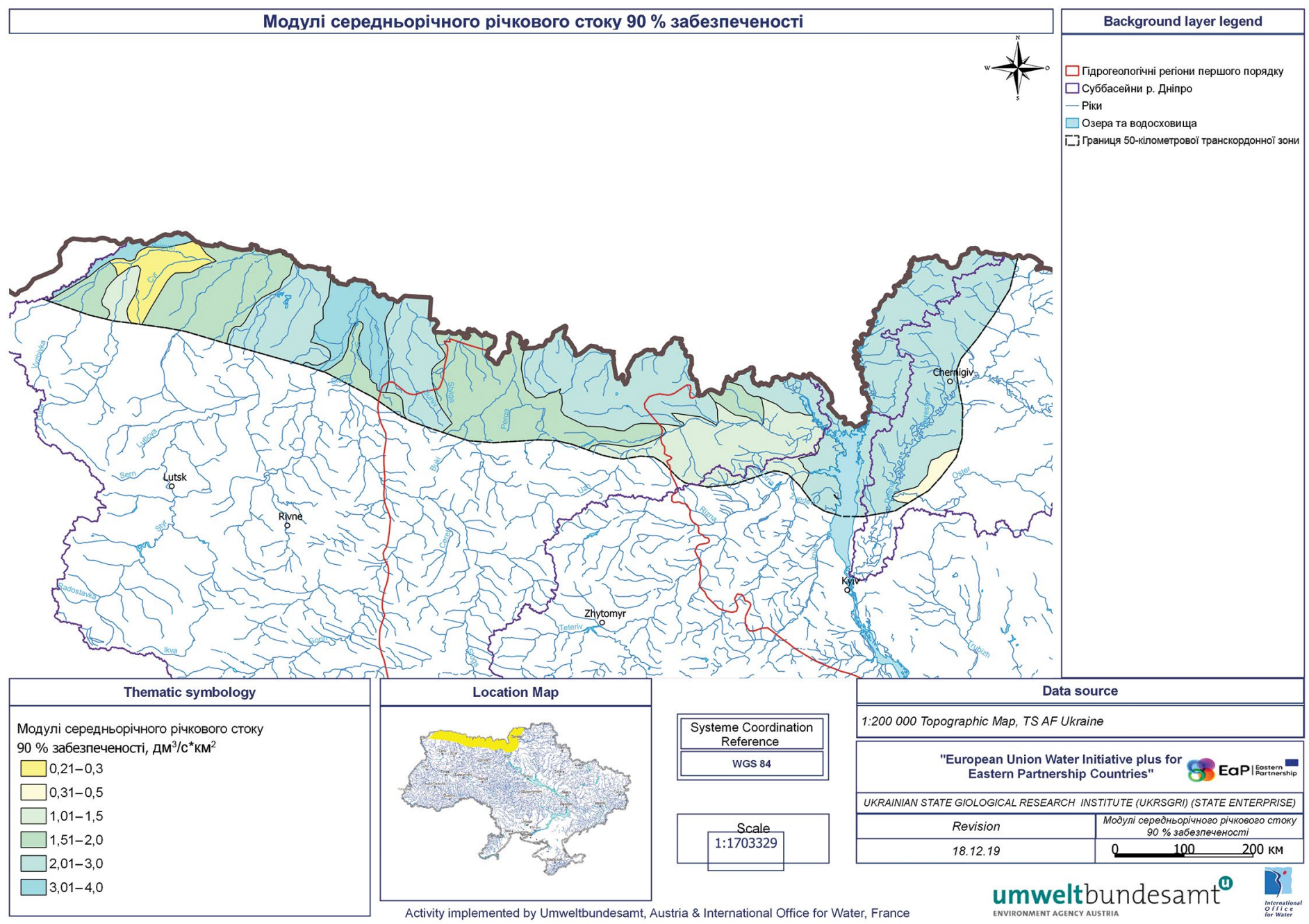

Рис. 2. Карта модулів середньорічного річкового стоку 90 \% забезпеченості 
ного водотриву між альбськими й сеноманськими відкладами немає, у їхній товщі виокремлюється єдиний водоносний комплекс.

МПВ в ефузивно-теригенних породах докембрію пов'язаний з утвореннями волинської серії нижнього венду та поліської серії середнього - верхнього рифею. Хоча докембрійські відклади в межах української транскордонної 50-кілометрової зони поширені суцільною смугою від схилів Українського щита (УЩ) на сході до межі басейну Дніпра на заході, для господарсько-питних потреб водоносний горизонт у докембрійських породах використовується лише в межах західного схилу УЩ на площах неглибокого залягання відкладів. У цій смузі завширшки 9-50 км на межі з УЩ він виокремлюється як МПВ в ефузивно-теригенних породах докембрію.

Що стосується якості підземних вод, то вона переважно добра, хоча є низка компонентів з природним підвищеним умістом у підземних водах заліза, мангану тощо. Крім того, актуальним питанням для обох сторін є забруднення довкілля внаслідок аварії на Чорнобильській АЕС, що потребує відповідного коригування переліку контрольованих показників якості підземних вод у процесі моніторингу.

\section{Висновки і рекомендації}

Прогнозування впливу експлуатації водозаборів підземних вод з огляду на їхню максимально можливу продуктивність із затвердженими експлуатаційними запасами свідчить, що радіус такого впливу становить для еоценового горизонту лише 3,54-9,38 км, для верхньокрейдового - 2,7-5,3 км, для альб-сеноманського - 2,8-6,7 км, для докембрійського - 1,7-2,3 км. Водночас відстань до державного кордону між Україною й Білоруссю від цих горизонтів відповідно становить 12-50, 7-50, 20-50 і 30-35 кілометрів. Вплив від розосереджених невеликих користувачів, які розробляють підземні води відкладів транскордонних МПВ, незначний і його не варто брати до уваги.

Отже, проаналізовані дані підтверджують, що транскордонного впливу на кількісні показники підземних вод у МПВ еоценових відкладів з боку України на Білорусь немає.

Щодо якісних показників, то впродовж 30-50-річної експлуатації водозаборів на цій території хімічний склад підземних вод був стабільним, а з огляду на сучасні тенденції до зменшення видобутку підземних вод в Україні, причин для його погіршення немає.

Загалом треба зауважити, що проведене дослідження є лише першим етапом з відновлення моніторингу МПВ на кордоні України з Білоруссю. Для докладного вивчення гідрогеохімічних і гідродинамічних процесів, що відбуваються в транскордонній зоні, треба як відновити спостереження на наявних свердловинах, так і залучити нові спостережні свердловини, а також узгодити процедури моніторингу, як-от: розміщення спостережних пунктів, періодичність спостережень, перелік контрольованих показників, та організувати постійний обмін інформацією з білоруською стороною.

\section{ЛIТЕРАТУРА}

1. Берёзко О., Васнева О., Черевач Е., Буйневич О., Кононова Т., Вицен И. Трансграничные под-части подземных водных объектов в бассейнах рек Припяти и Днепра на территории республики Беларусь. - Филиал “Институт геологии”, Государственное предприятие “НПЦ по геологии”,2020. https://www.euwipluseast.eu/images/2020/12/ PDF/BY-Transboundary-GWB_RUS-final.pdf

2. Гошовський С. В., Саніна I. В., Люта Н. Г. Технічний звіт “Ідентифікація та розмежування підземних водних об'єктів у басейні річки Дніпро в Україні”, 2019. https://www.euwipluseast.eu/ images/2019/04/GWB-Delineation-DNIPRO_UA_final.pdf
3. Соболевский Э. Э. Оценка перспектив расширения использования ресурсов питьевых подземных вод в народном хозяйстве УССР. Отчет. - 1981

4. Стан підземних вод Украӥни. Щорічник. - ДНВП “Геоінформ України",2020.

\section{REFERENCES}

1. Berjozko O., Vasneva O., Cherevach E., Bujnevich O., Kononova T., Vicen I. Transboundary sub-parts of groundwater bodies in the basins of the Pripyat and Dnieper rivers on the territory of the Republic of Belarus. - Filial "Institut geologii", Gosudarstvennoe predpriyatie "NPC po geologii", 2020. https://www.euwipluseast.eu/images/2020/12/PDF/ BY-Transboundary-GWB_RUS-final.pdf (In Russian).

2. Goshovskyi S. V., Sanina I. V., Lyuta N. G. Technical Report "Identification and delimitation of groundwater bodies in the Dnieper River Basin in Ukraine", 2019. https://www.euwipluseast.eu/images/2019/04/ GWB-Delineation-DNIPRO_UA_final.pdf (In Ukrainian).

3. Sobolevskyi E.E. Assessment of prospects for expanding the use of drinking groundwater resources in the national economy of the USSR. Report. - 1981. (In Russian).

4. State of groundwater in Ukraine. Yearbook. - DNVP "Heoinform Ukrainy",2020. (In Ukrainian).

Рукопис отримано 22.03.2021.

\section{MHIFPPIABDII PECYPCH YKPFIIHIII}

Редакція приймає оригінальні, раніше не опубліковані статті геологічної, геолого-мінералогічної та технічної тематик.

Статті треба надсилати в друкованому (два примірники) й електронному вигляді, бажано українською мовою.

Обсяг однієї наукової статті - до 25 стор. машинопису через 2 інтервали (разом з табл., фото, рис. та підписами до них, бібліографічним списком, анотацією), оглядової - 6-7 стор., інформаційного повідомлення - 3-4 стор.

До рукопису потрібно додати акт експертизи й такі відомості про автора/авторів: прізвище, ім'я та по батькові (повністю); учене звання й учений ступінь; посада чи професія; місце роботи (назва установи чи організації); адреса місця роботи, номер телефону; адреса місця проживання, номер телефону, електронна адреса, ORCID.

До кожної статті обов'язково навести: індекс УДК, анотацію (українською та англійською), бібліографічний список за алфавітом (оформлений відповідно до сучасних вимог), рисунки, таблиці та підписи до них (окремі файли).

Комп'ютерні макети рисунків приймаються в разі дотримання таких умов:

Рисунки подаються окремими файлами, їх не потрібно розміщувати у файлі документу MS Word.

Р а с т р о в а графіка: чорно-біле зображення - *.tif чи *.psd (Adobe PhotoShop); повнокольорове зображення - *.tif, *.eps, *.psd-формат, роздільна здатність 300 dpi. Кольорова модель СМҮК, чорний колір в одному каналі.

В е к т о р н а графіка: файли формату *.ai, *.eps (Adobe Illustrator) чи *.cdr (CorelDraw). Використані шрифти мають бути подані окремо або переведені в криві. Растрову графіку до векторного макета не вносити.

- Редколегія може не поділяти думок автора.

- Автори відповідають за точність викладених фактів, даних, цитат, бібліографічних довідок, написання географічних назв, власних імен, геологічних термінів тощо.

Рішення про публікацію статті в журналі приймається на основі незалежної експертизи, яку організовує редакція журналу. 